УДК 7.032

ББК $63.4(3)$

DOI: $10.18688 /$ aa2111-01-13

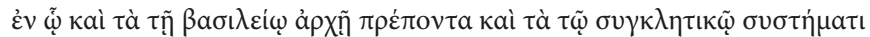

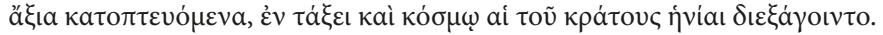

Const. Porph. De cerimoniis aulae Byzantinae, lib. 1:

T. Mavrogiannis

In Memory of Angelos Delivorrias

\title{
The Great Frieze of the Parthenon and the Organization of the Athenian Society under the Democracy of Pericles
}

The aim to examine once again how the Athenians appear to be organized in the iconography of the Great Frieze of the Parthenon is less ambitious than the title given to this paper. I refrain from any kind of methodological premises because they come to light only after having faced the evidence through the empirical way. Regarding evidence, I mean the Frieze itself as a concrete codified system and the written sources, mainly the antiquarian ones. To balance between the objectivity of Archaeology and the indirect nature of the literary tradition is a true challenge. The problem of the criteria used for the composition of the Frieze of the Parthenon is still enormous. There are many theories, which cannot be proved, trying to objectify the criteria applied to the Frieze, as well as many reconstructions by historians of the society of Classical Athens, without grasping the essence, since they do not include in the evidence the Frieze [2; 3; $6 ; 7 ; 20 ; 21]$. The knights have often drawn attention as regards number, position, appearance, and clothing. Evelyn Harrison believed she had discerned that the disposition of the knights on the South side (Fig. 1) of the Parthenon was dictated by the number 10, reflecting the subdivision of the body of the Athenian citizens in 10 territorial tribes by Cleisthenes in 508/7 B. C. [7]. Thus, the organization of the knights in $6 \times 10$ sextets (Blocks South I-XXIII + XXIV $=$ 1-59-60) would be the proof for her and Luigi Beschi that the new democratic criterion of number 10 ruled upon the whole representation on this side, including the 10 chariots of hoplitai (Blocks South XXV-XXXV $=62-88$ ) who follow and the third nucleus which is concluded with 10 heifers to be immolated by 2 persons who accompany them (Blocks South XXXIXXLVII $=+120-149)[1, \mathrm{pp} .120-122]$. The procession of 4 aged men, on the background of the victims, were seen as a group of kitharodoi (Blocks South XXXVII-XXXVIII $=107-110$ ). However, as L. Beschi underlined, W. Schuchardt and F. Brommer rightly recognized that they bear rectangular tablets $[19,4]$, similar to the pinakes in which Beschi recognized the tamiai of the "Sacred Money of Athena". The tamiai annually registered the financial statement of the $\tau \dot{\varepsilon} \tau-$

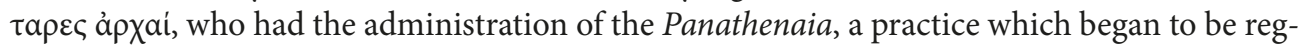
istered in four columns in the preserved inscriptions from the Great Panathenaea celebrated in

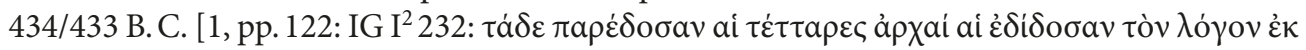




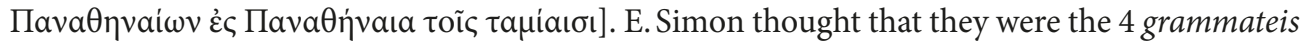
of the following group of 18 elders, although the tamiai were in fact 10 and not 4 [Ath. Pol. 47, $1 ; 13 ; 10$, pp. 48-54]. The most serious obstacle for applying the number 10 comes in effect with the group of the 18 old men (Blocks South XXXVI-XXXVII $=89-106$ ). Being ahead of the tamiai, they would represent 8 Archons and 10 political groups, one for each Cleisthenian tribe $[1$, p. 122]. But the College was composed of 9 Archons and there is the significant exception of the Archon Eponym, who is absent. L. Beschi extended the criterion to the main façade of the representation, the East side (Fig. 2): 10 Ergastinai, bearing the 5 of them a phiale and the other 5 the oinochoai for the libation (Blocks East I-III $=2-17+$ VII-IX $=53-63$ ). They are arranged in the two extremities. In between, there are 10 men who frame in two groups of 6 and 4 (Blocks East III-IV $=18-23+$ VII $=46-49)$ the Council of the 12 Olympian Gods embracing in the center of the composition the climax scene, the delivery of the new peplos for Athena Parthenos (Block East $\mathrm{V}=31-35$ ). The group of 10 men cannot, therefore, but be identified with the 10 Eponymous Heroes corresponding to the 10 territorial tribes of the Democracy of Cleisthenes, though they do not appear in a division of $5+5$ which is the number of the Council of 500 . And yet, there arise a few other problems: It seems that Block XXXVII* South, identified by F. Brommer and accepted by L. Beschi, seemingly doubted by A. Delivorrias [4, p. 99, Taf. 152], depict skaphephoroi, bearing each a skaphe, a trough [1, p. 122], and XXVII South, accepted only by F. Brommer [4, p. 98, Taf. 110, 113] and apparently by L. Beschi, as well as the 3 skaphephoroi (Block North $\mathrm{V}=13,14-15$ (through the design of Carrey, except for the first one n. 13). There emerges another serious discrepancy of the system, since the skaphephorein is undoubt-

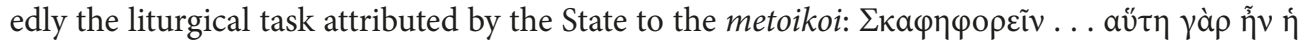

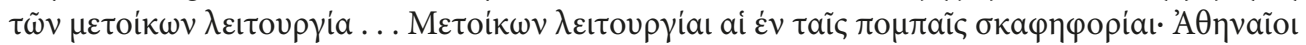

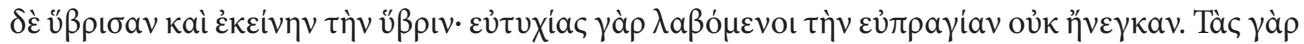

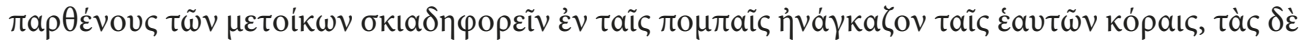

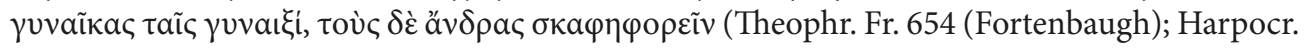

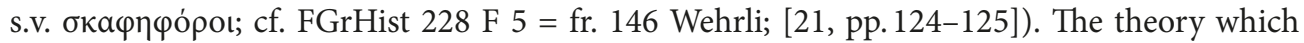
splits the composition of the Great Frieze in two arithmetical and political mechanisms (South side Cleisthenian, North side Solonian), seems to be far-fetched. It is not only the Cleisthenian half of this counterpart structure which nowadays has prevailed as a strong interpretation, since on the other long side of the Parthenon, facing North (Fig. 3), the number 4 would be the magical number revealing as criterion of the representation the subdivision of the Athenians in 12 phratriai, 3 for each one of the 4 tribes, according to kata ta patria, "the religious institutions

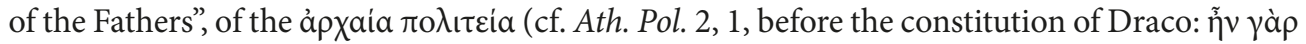

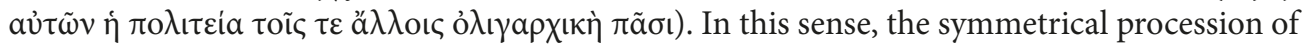
the knights, which is displayed from the south-west corner of the Parthenon and develops $6 \times$ 10 in sextets +2 knights (Blocks North XXVIII (though highly controversial and hypothetical by A. Delivorrias) - XLVII = 72-136), would be in accordance with the number 4 reflecting the 4 Archaic genetical tribes. Therefore, L. Beschi linked to this side the preparatory parade of the knights on the South façade of Parthenon, in such an order to generate 14 groups $\times 6$, in a total of 84 knights (North $134-72=62+2=64$, South $1-30=20+64=84$ ), which is not divisible by 4 . He was right to interpret the 2 knights standing on the Block North XLVII (133+ 135) as interconnected to the gesture of re-ordering the parade on the Block West I, 1 (Fig. 4), 


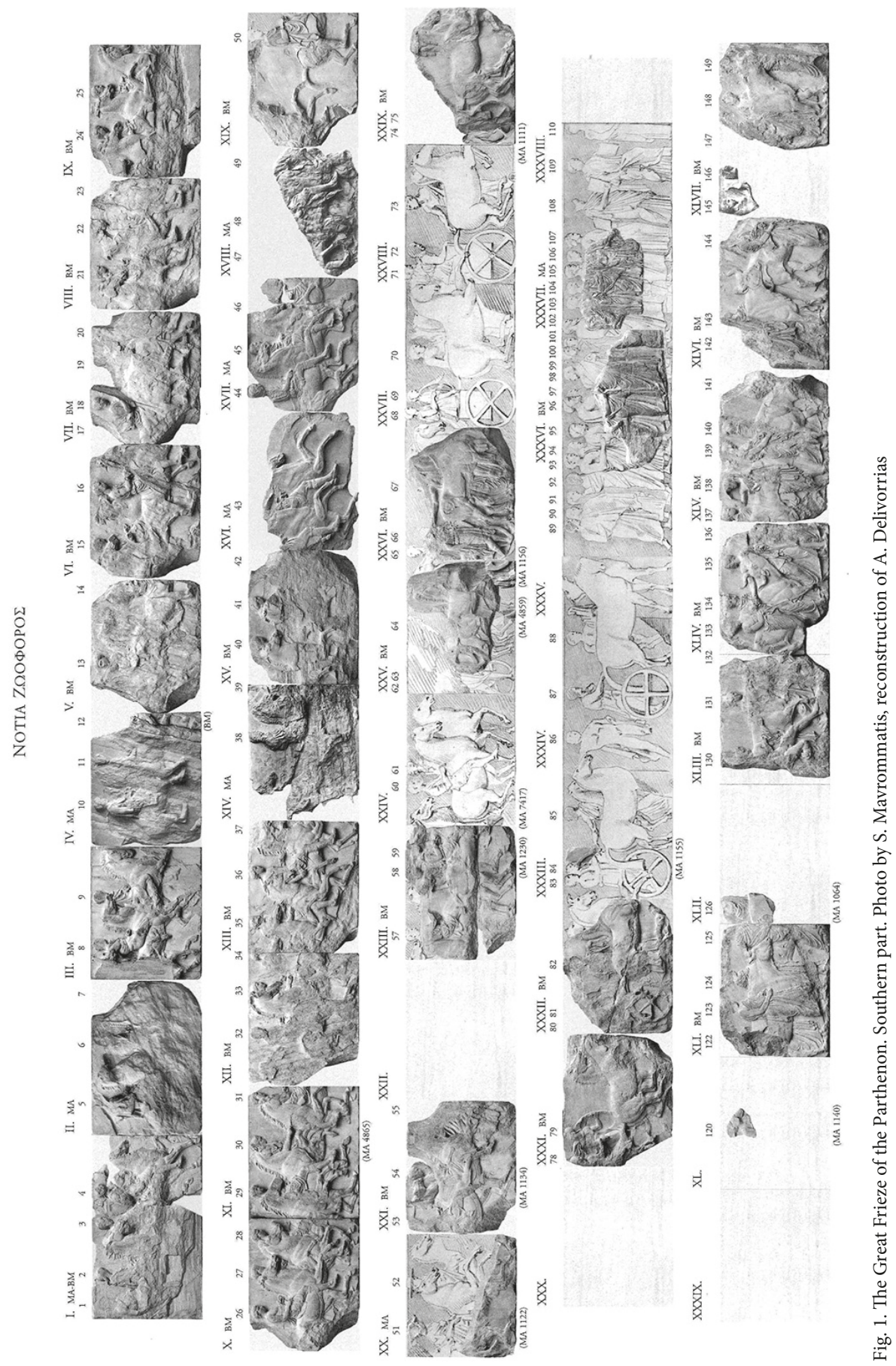



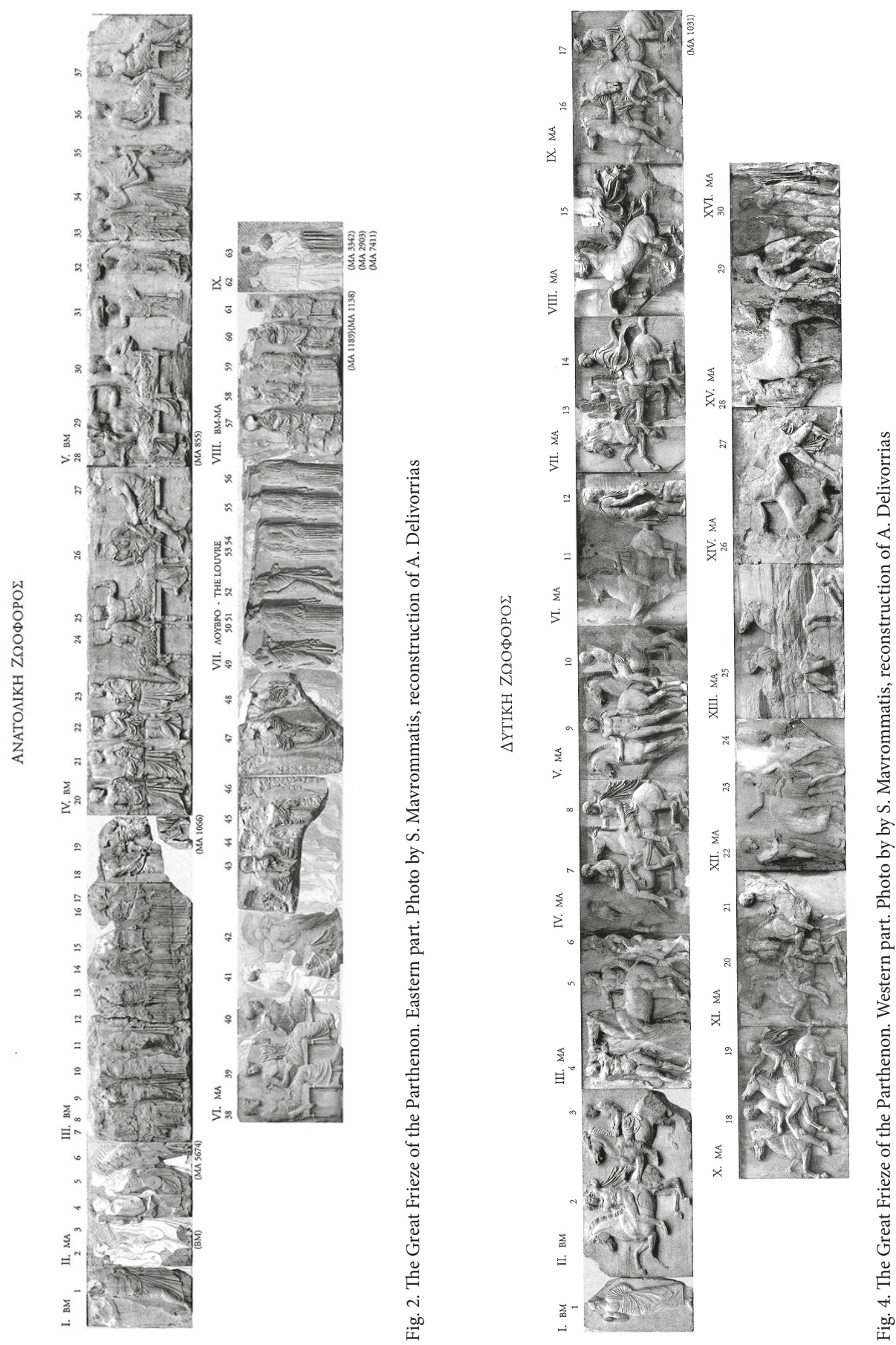

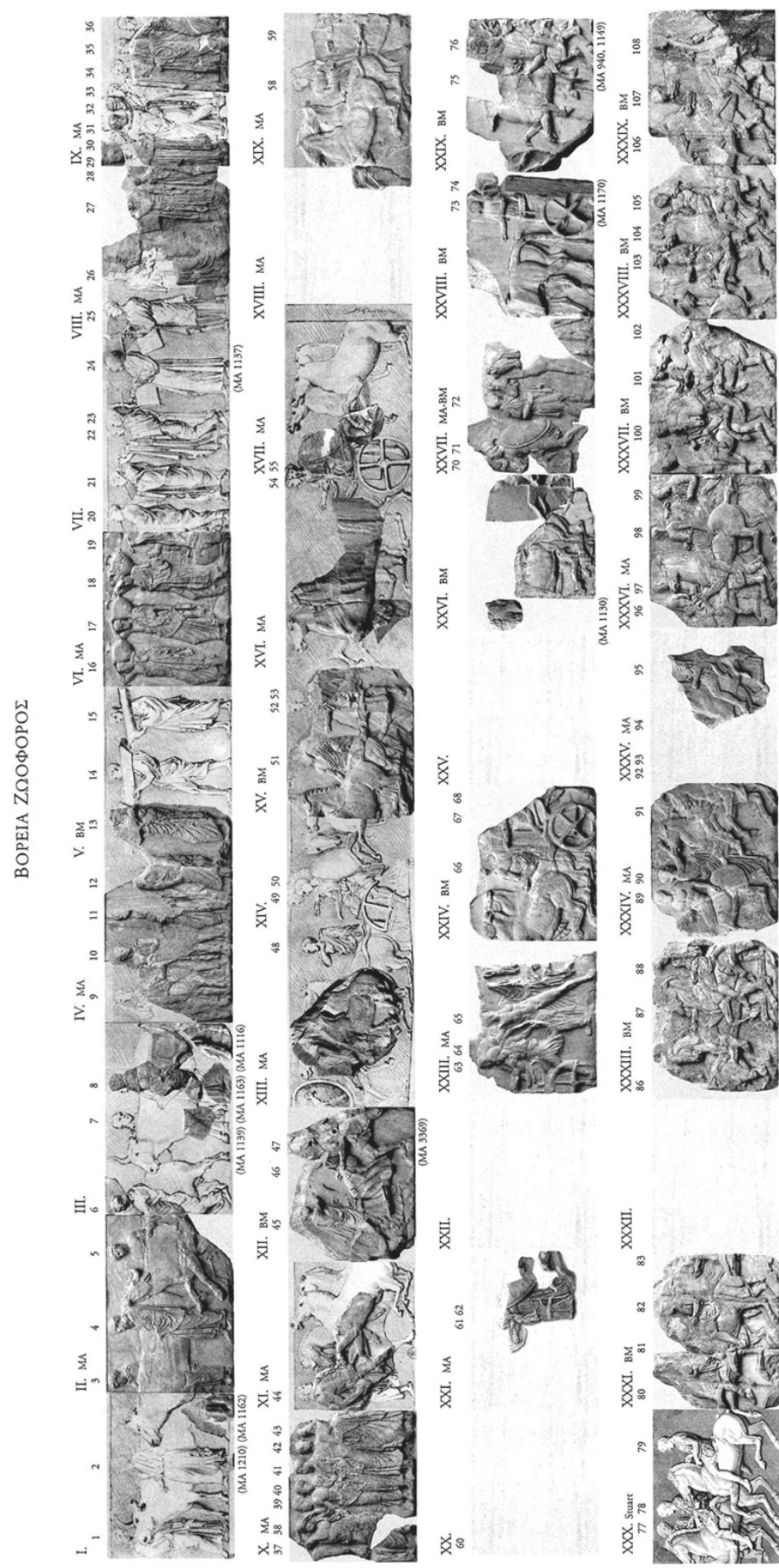

㠃 $3^{2}+1(3)$

$\because 2 x^{2} \frac{5}{12}$

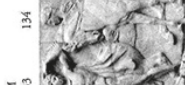

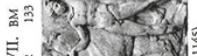

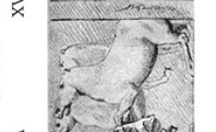

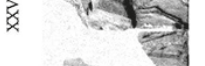

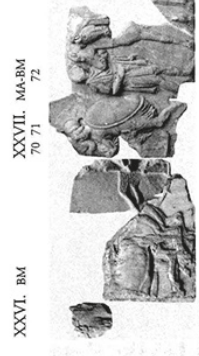

$\therefore 70$

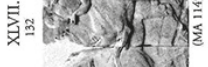

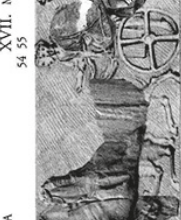

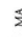

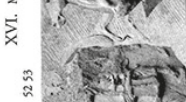

क्ष

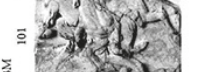

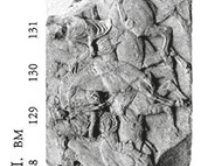

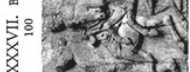

a $\rightarrow$ if

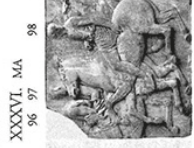

通 $=0$

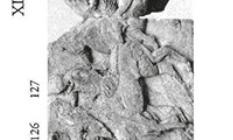

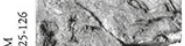

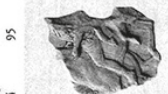

爻
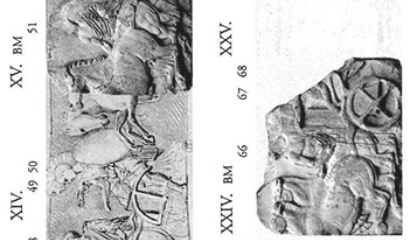

इ2

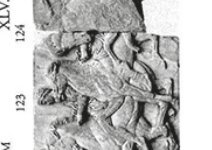



শ্xंs

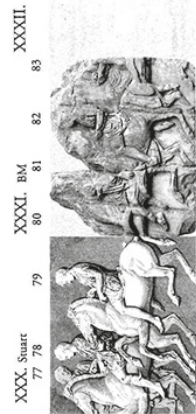

: $2 x+2 l^{x}$

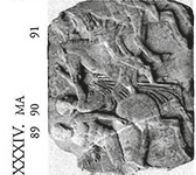

又

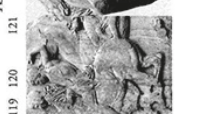

$=2 \mathrm{cs}$

离 $(\pi)=1)$ in

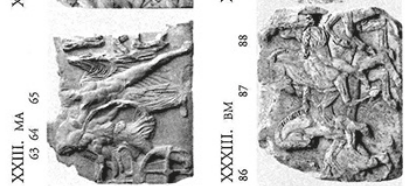

宊 एका

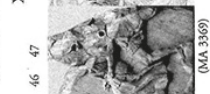

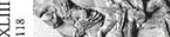

(a) 3 is

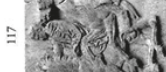

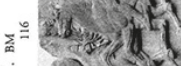

范气 31 .

$=p^{2}(5)^{2}$

-a 21

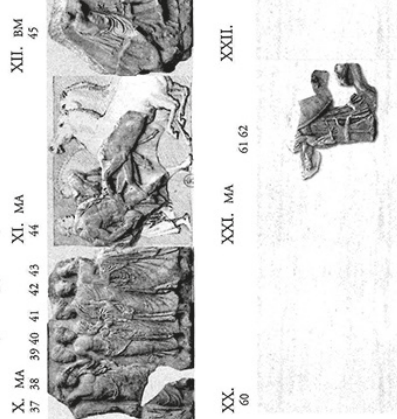

$=3680$

i s ol

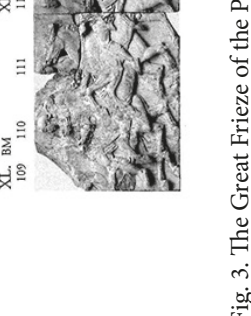


so that we shall have, in fact, two groups well distinguished, $6 \times 10$ and $6 \times 4$, and not a broken sextet. L. Beschi enhanced this reading by proposing to include in the two-fold system of Harrison the 12 chariots of hoplitai which are represented according to the original dokimasia of the apobates agon, to be held in the Agora of Athens (Blocks North XXVII - XI = 71-44). According to number 4, the 16 old men, certainly recognized as thallophoroi by the attribute of the branch of olive tree they bear in hand (Blocks North VIII-X $=28-43$ ), would respond to a subdivision of $4 \times 4$. The number 4 would appear also in the 8 musicians, $4+4$ (Blocks North VII-VIII $=28-26+25-20$ lost), in the representation of the 4 hydriophoroi (Blocks North V$\mathrm{VI}=15-18$ ) and finally into the number of the victims, being $4+4$ (Blocks North I-IV $=1-8$ ).

It is not only the symmetrical presence on this side too of 3 skaphephoroi - metoikoi (Blocks North V $13+12,14$ lost) which creates a lot of doubts about the intention of Pheidias. Nobody commented clearly on what period of the Archaic Athens one would put the subdivision of the Athenians in phratriai, which actually goes back to the aristocratic polis of $683 \mathrm{~B}$. C. This is more urgent to be clarified because the number 4 giving 12 trittyes for each genetical tribe was used as criterion by Solon in 594/3 B. C. in his division of the Athenians into 12 trittyes. The problem is that Solon substituted the 12 phratriai through 12 trittyes without altering the relationship with the 4 tribes [16, pp.93-100]. And this has further consequences since the 12 trittyes were subdivided from Solon into 48 naukrariai - "district of equipment of a ship" [16, pp. 79-92]. Unfortunately, we do not know what the institution of the naukrariai was exactly and there is no trace, apparently, among the groups of the Frieze, although the Athenaion Politeia of Aristoteles provides peremptory clues to this point. I insist, because there existed some considerations which push the evidence towards the direction of a global analysis of the body of the knights, not as a two-fold political system reflecting different ages and different stages of the Athenian Constitution. In that case, there is no need to distinguish between two parallel columns of knights. They show that the only valuable criterion of the representation is the number 60 and $60+2$. The addition of two knights does not touch upon the symmetry of the two series. There is neither a fault nor a second thought by Phidias, but only the necessity to hold the startup. There is no space for too complicated political readings of the Frieze. If there is a magical number, this is indicated, not hinted at. The only element to be evaluated is the fact that the knights are 144, according to the most reliable computing of L. Beschi. Their structure is in 24 sextets or halves of dozens. Thus, in order to decodify the number 144, we have to take into consideration that this number can be divided by 3 , neither by 4 nor by 10 . And since the division 144 by 3 gives 48, we may assume that the general criterion was the division of the 4 tribes of Solon into 12 trittyes, not anymore in phratriai. Three is the number of reference and $4 \times 3$ is the constant ratio. The system of the knights seems to be based on the relation trittyes/naukrariai of the Solonian constitution. At this point two problems emerge. First, nobody believes that the naukrariai continued to be held in office after Cleisthenes, since this particular system would have been abolished by Themistocles in 483 B. C. Secondly, what does a representation kata ta patria mean, as described by the Athenaion Politeia for Cleisthenes? Let us see the passage: 21 , 5-6: "He set up Demarchs with the same functions. . He left the citizens free to belong to clan groups, and phratries, and hold priesthoods in the traditional way" [cf. the political slogan patrios politeia - "constitution of the ancestors", in Athens in c. 411 B. C.). Cleisthenes did not abolish the division of the Athenians in 4 genetical tribes and 12 phratriai, which were composed by 
30 clans-gene, each one with 30 members (Ath. Pol. fr. 3; 15, p. 248). He insisted on separating the political division, giving access to the bodies of power, and the genetic division, based on the common blood. Thus, although he intervened in the system of participation to the Council of 500, he refrained from altering the genetic division, still valid in a so-called religious field. We are dealing with two parallel structures. Many doubts arise as to whether the procession of the Great Frieze reflected the political order of Cleisthenes, including the institutions kata ta patria, or mainly the most profound roots of the Athenian "brotherhood". No surprise, there cannot exist a Solonian version of the Athenian Constitution on the Frieze without the representatives of the 12 trittyes, since only 12 gives the total number of 144 . At any rate, there is no space for the 30 trittyes of Cleisthenes. Once again, modern commentators exclude that Solon instituted the trittyes, as being an invention of Cleisthenes, although they already appear in the number of $4 \times 3=12$ in the text of the Athenaion Politeia under Solon (Ath. Pol. 8, 2). What is then the concrete relationship between phratriai and trittyes and how is this expressed by the term kata ta patria? S. D. Lambert is outspoken at this point [13, pp. 245-261]: The phratriai are the genetic subdivisions having to do with the admission of the Athenians into the citizen body through inscribing them in tablets - pinakes during the feast of Apatouria by the phylobasileis. We do not have any kind of evidence that this practice was abolished after Cleisthenes. The temples of Apollo Phratrios and Athena Phratria still stood in the Agora of Athens in the $4^{\text {th }}$ century B.C. Trittyes are the units of the military organization according to the phratriai. We should accept that when the Athenians reached the age of 18, they had to be registered from their 12 phratriai into one of the 12 trittyes according to their revenue: an operation of census. This might be the novelty introduced by Solon, the updating of the phratriai in trittyes for military purposes according to census - time. And this is the reason why the trittyes fit together with the naukrariai as far as their function is concerned. Although our knowledge about the naukrariai is limited, we have at our disposal a precious text of Pollux, Onomastikon, 8, 108, in which the naukrariai also appear to hold military functions as units of recruitment for knights

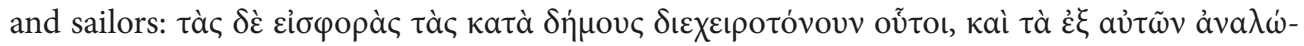

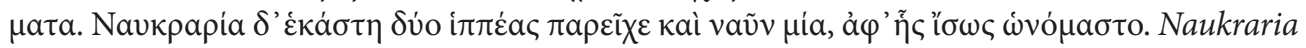
was primarly a district of financial administration. At the same time, as the naukraroi were summoned to pay, they constitute units of military recruitment for knights and sailors, notwithstanding that they were responsible for the equipment of the ships. Each naukraria is said to produce 2 knights and 1 ship. If we accept the notice, we would have as basic unit of the Athenian cavalry the number of 96 knights. Of course, it is difficult to accept that the recruitment unit for the knights in the passage of Pollux was the Solonian trittys, since 2 knights for each naucraria would produce 8 knights for 12 trittyes, rendering the ratio 3 by 144 impossible. And yet, there is no reason to emendate the passage, if we accept that it refers to the recruitment of the knights occurred under Cleisthenes, not at all to the recruitment process under Solon which seems to be represented on the Frieze of the Parthenon. The demonstration lies in a passage of Kleidemos, who wrote an Atthis around 350 B. C., reported by Photius (FGrHist $323 \mathrm{~F}$ 8), s.v.: "Kleidemos says in his third book that, when Cleisthenes created the ten tribes in place of the four, it was done in such a way that they were arranged in fifty groups which he called naukrariai, just as now they call the division into a hundred parts symmoriai". Despite critics, I prefer the authority of F. Jacoby who postulates that Cleisthenes added 2 naukrariai to 48, thus 
the number of the knights under Cleisthenes could not be 96, which is otherwise unattested, but 100. Cleidemos speaks of 50 naukrariai. With 48 naukrariai we had a different system of computing, prevailing in the whole of the frieze, not in a single part of it. If, for instance, the recruitment entailed 2 knights for each trittys, which is what we would have expected for Solon, we will have $12 \times 2=24$ knights or $12 \times 12$ trittyes $=144$ hippeis. We comprehend better the iconographic choice 10 sextets +10 sextets +4 sextets $=24$ sextets. Twenty-four lines profound $\times 6$ lines in front gives 144. This is precisely what is depicted on the Great Frieze, according to L. Beschi.

The 144 knights are divided in 48 naukrariai, 3 for each naukraria and not 2 as Cleidemos says for Cleisthenes. The magical numbers are 3, 6, 12, 24, and 48. And this must correspond to the Solonian recruitment. But, there must be an evolution: As $24 \times 48$ gives 1.152 knights, it is almost certain that this is the approximate number of 1.200 knights reported by Thucydides for the Athenian cavalry in 431 B.C. [Thuc. 2, 13, 8; 26, pp.97-98, 124; 29, p. 70]. In other words, this is the cavalry of Pericles, which is not based on the pattern of Cleisthenes but on the model of Solon: "C'est probablement dans leurs rangs que seront recrutés les militants de la revolution oligarchique de 404 et les partisans les plus extrémistes des Trente Tyrants" [25, p. 221]. There is the suspicion that Pericles reintegrated in the State the recruitment of the knights according to 12 trittyes of Solon. How do we explain the perfect number of 144 knights, without the Solonian subdivision? How could we, after that, explain this divergency by the democratic reform of Cleisthenes, who through a radical process rendered the State "more Democratic", as the Athe-

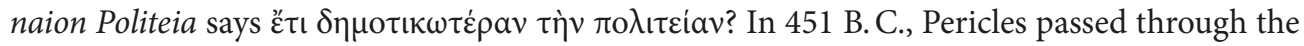
Assembly of Demos a law on the Athenian citizenship. Only those who were born to an Athenian father and an Athenian mother had the right to participate in the State. It is very difficult to reconstruct the details. There is a general belief that citizenship was determined by membership in a phratry, already in the early Archaic times, in the period of phylai, phratriai and gene, at any rate before Solon. And yet, this is excluded by Philip Manville in his book on the Athenian Citizenship. However, nobody can deny, thanks to the inscriptions, that the living process in the $5^{\text {th }}$ century B.C. Some evidence suggests that the phratries were already in the $7^{\text {th }}$ century B.C. military divisions. This is very important, since the introduction in a phratry at the moment of birth would imply the recruitment, in a second time, through the certificate of the phratry. Recognizing legal births, marriages, and adoptions must be the first level of application of the law of 451 B. C. It is normal that these tasks were assigned to the phratriai. From the moment the Athenians decided to close their citizen body, it was necessary to enable and to renew the old genetic institutions. There was no other way in order to guarantee the legal descendance of an Athenian by both Athenian parents than the process of phylokrinein, what was literally abolished by Cleisthenes. I suppose that when we see on the Frieze the 4 hydriophoro $i$ who allude as participants to the feast of Gamelia, this is what follows the admission to the Phratries for the Athenian girls, as well. The 16 old men called thallophoroi could represent

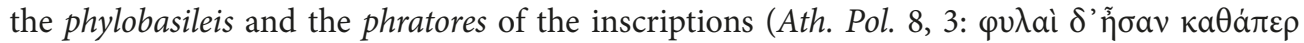

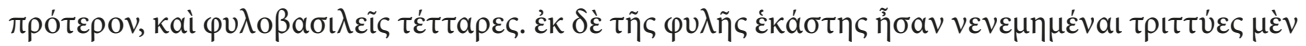

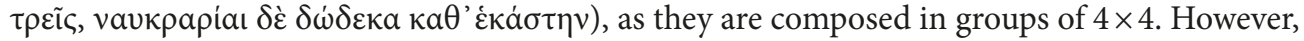
the principal and ultimate aim of the citizenship law of 451 B. C. might have been the recruitment of the new Athenian citizens as hippeis, hoplitai and thetai into the Athenian army. A 
military reform due to Pericles, which is unattested in the written sources, is presupposed by the organization of the knights on the Frieze of the Parthenon. This means that it is not simply the religious procession of the Panathenaic festival which is represented on the Parthenon, but the procession of the City in honor of Athena Parthenos which follows and, therefore, sanctions the proofs for the recruitment of the new Athenian citizens in the army, according a dokimasia

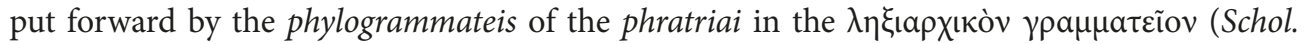

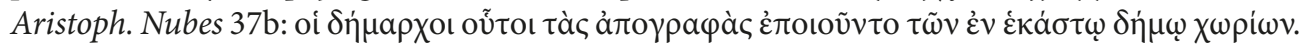

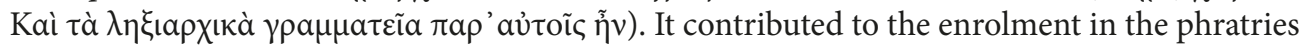
of boys and girls during the Ionian feast of Apatouria, but it had a military perspective for the boys. This is the reason we have to distinguish between enrolment and recruitment, between 12 phratriai and 12 trittyes, between the aristocratic constitution of 683 B. C. and the Solonian reform. In fact, it seems that they had adopted the pre-Solonian and the Solonian solution to fix the citizen body with the Law of 451 B. C. In other words, the phratries were reintegrated by Pericles in his Democracy in their historical evolution. And yet, the main problem is the fixed number 144. As it is divided in 48 naukrariai through the trittyes, we cannot help but wonder, which is the unit of military recruitment under the Democracy of Pericles, the trittyes or the naukrariai or perhaps both? If we recognize that the naukrariai preexisted and if we accept that they were not abolished by Cleisthenes, how do we explain the absence of the naukraroi from the Frieze when we understand the system of census? The Athenaion Politeia of Aristoteles pinpoints officials who have financial tasks in the administration. These are the Tamiai - "Treasurers of Athena", the kolakretai, the "Collectors of common funds", and the naukraroi, being in charge of organizing the raising and maintenance of a ship, following the criterion of the residence in definite local ship-providing districts, the naukrariai. The Athenaion Politeia insists as well that the naukraroi were responsible for the collection of levies and expenditures in local areas. I cannot understand why some scholars deny that their main charge was a liturgical levy, paying for ships or ships and crews, in fact an original kind of the trierarchia. V. Gabrielsen

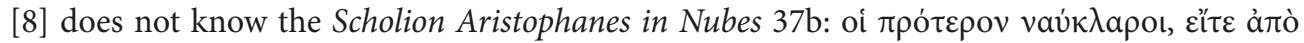

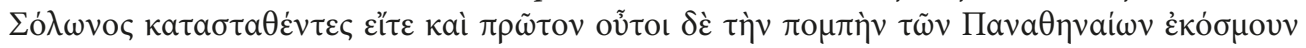

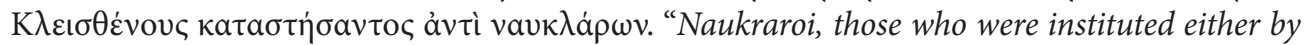
Solon or before Solon. They decorated the procession of Panathenaia. Cleisthenes instituted them in the place of naukraroi". Here lies the essence of the problem:

1) It is certain that the naukraroi were represented on the Frieze;

2) Their origins could go back to the archaia politeia;

3) They must have been the representatives of the thetai, as the Captains of the crews;

4) The thetai would be absent from the procession of the Panathenaia, limited to hippeis and hoplitai;

5) There cannot be complete recruitment without the levy of the thetai for the navy at the age of Pericles.

6) There cannot be Democracy of Pericles without even a hint of the thetai on the Frieze.

The theories that the naukrariai were abolished by Themistocles or that they had nothing to do with the financing of the fleet at the Age of Pericles, are pure phantasies, as it is demonstrated 
by the number 144 and the testimony of Cleidemos. The naucrariai did not only survive but they also had the primary role in the recruitment of the crews after $451 \mathrm{~B}$. C. There is also the possibility that the naukrariai played a role in the process of phratrizein, to certify the Athenian origins, which would connect the naukrariai to the phratriai of the archaia politeia. This would make plausible the idea that the phratria was originally responsible for the ships as naukraria,

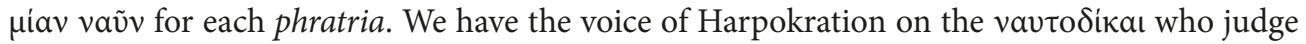

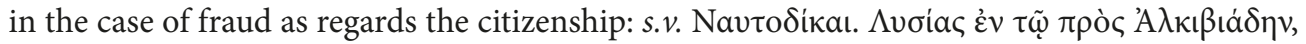

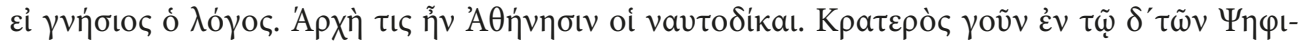

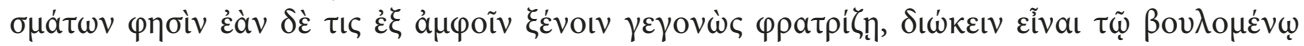

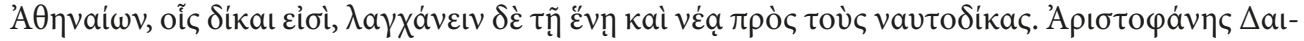

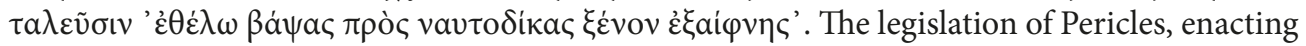
the limitation of the citizen body, is the counterpart of the myth of the Athenian autocthony, a concept which legitimize their cultural superiority. This myth is represented on the base of the statue of Athena Parthenos. It is the first, the apparent level. The other level is given by the primacy of the naukraroi and the hinted position of the thetai - the crews of the ships on the Great Frieze. Pausanias 1, 21, 1 and the voice of Suda attest that the peplos of Athena was carried on a ship's mast, ítiov, kepaia. The Lexicon Seguerianum (Anekd. Bekkeri I, 283) says that the naukraroi were subordinated to the polemarch, just as the strategoi named the trierarchs in the Democracy of Pericles. It is Herodotus $(\mathrm{V}, 71,2)$ who preserved that the prytaneis of the

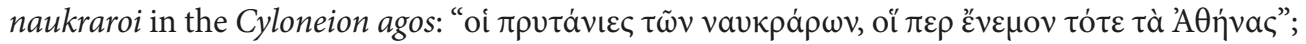
"the very ones who administered Athens, then". I guess that the Themistoclean naval reform of 200 triremes, attested by the "Decree of Themistocles", did not affect the living memory of the naukraroi into the archaia politeia.

Thus, the celebration of the Great Panathenaia, following the census operation which started with the proofs for the admission to the new citizen body and was achieved through the recruitment of hippeis, hoplitai, and sailors, constitute the two faces of the Law of $451 \mathrm{~B}$. C. The importance of the Citizenship law for the future of Athens was both determinant and radical. The building of the Parthenon was commenced in 447 B. C. The Great Frieze was placed on the walls of the cella of the Parthenon in 438 B. C. It is a pity that we do not know what turned out in terms of application of the Law. Is it conceivable to expect a return to the recruitments criteria of the archaia politeia in the age of Pericles, or is it only the history of the Athenian Constitution before Cleisthenes which is depicted on the Parthenon? In this answer lies the assessment of how democratic the Democracy of Pericles was, in comparison to the Constitution of Cleisthenes. The decision to immortalize the new organization of the Athenians on the Frieze of the Parthenon seems to be really the consequence of the Citizenship Law of 451 B. C. It went back through the Solonian measures to the archaia politeia of the homogalaktoi - "those generated by the same milk", deemed to be preserved by the Democracy of Pericles. Thomas Figueira rendered the best treatment of the question about the origins and the functions of the naukraroi in Athens [9, pp. 184-205], overwhelmingly hypercritical approaches which do not have any idea of how significant the presence of the naukraroi for the Great Panathenaia and the Frieze of the Parthenon was. It was Peisistratos in the year of Archont Hippokleides 566/5 B. C. who assigned the responsibility of the Great Panathenaia precisely to the body of the naukraroi. It was the first time that the Great Panathenaia was celebrated. With a past behind it, their presence 
on the Frieze of Pheidias should be compulsory. Not only were they the first to administrate the procession, but also the naukraroi could exclusively represent the class of the thetai, which otherwise would have remained absent. This is really too much to be true. It is important to have established that the naucrariai were instituted before Solon, because we can confirm that the number of naucrariai and the naucraroi was originally 12, as the number of the phratriai, before Solon expanded their number to 48 and Cleisthenes to 50.

It seems that we return to the original subdivision of the aristocratic politeia. I think that we can split the political groups of $10+8$ on the South side into $12+6(3 \times 2)$. There must have been the prytaneis of the naucraroi present in the Periclean constitution and on the Frieze. This is the best place for the 12 prytaneis naukraron. It is tempting to conclude with a last remark. Cleisthenes would have substituted the naucrariai by the demoi and the naucraroi by the demarchoi, but without a definite correspondence to the number of the demoi, which is now 139 or 140, according to Traill. Are we sure that the number of the demoi of Periclean Athens was not fixed as well, instead of having followed fluctuations? Are we aware of the fact that there is the possibility to have 144 fixed demoi, as units of recruitment for the 144 hippeis and the thetai? Non liquet, we cannot say more than just pose the question. In any case, if we have hippeis, naukraroi and metoikoi on the Great Frieze, their participation in the leitourgiai of the State, as

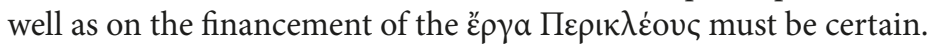

\section{References}

1. Beschi L. Il fregio del Partenone: una proposta di lettura. Atti della Accademia Nazionale dei Lincei, 1984, pp. 173-195 (in Italian).

2. Boardman J. The Parthenon Frieze: Another View. Höckmann U.; Krug A. (eds.). Festschrift für Frank Brommer. Mainz, Verlag Philipp von Zabern Publ., 1977, pp.39-49.

3. Boardman J. The Parthenon Frieze. Berger E. (ed.). Parthenon-Kongress Basel, Referate und Bericht 4 bis 8 April 1982. Mainz, Philipp von Zabern Publ., 1984, pp.210-215.

4. Brommer F. Der Parthenonfries: Katalog und Untersuchung. Mainz am Rhein, Philipp von Zabern Publ., 1977. 292 p. (in German).

5. Clerc M. Les métèques athéniens. Étude sur la condition légale, la situation morale et le rôle social et économique des étrangers domiciliés à Athènes (BÉFAR 64). Paris, Ernest Thorin Publ., 1893. 476 p. (in French).

6. Connelly J. B. Parthenon and Parthenoi: A Mythological Interpretation of the Parthenon Frieze. American Journal of Archaeology, 1996, vol. 100, no. 1, pp. 53-80.

7. Connelly J. B. The Parthenon Enigma: A New Understanding of the World's Most Iconic Building and the People Who Made It. New York, Alfred A. Knopf Publ., 2014. 528 p.

8. Delivorrias A. I Zoofóros toú Parthenóna. Tó próvlima, i próklisi, i ermineía. Athens, Melissa Press Publ., 2004. 192 p. (in Greek).

9. Figueira Th. J. The Athenian Naukraroi and Archaic Naval Warfare. Cadmo, Centro de Historia da Universidade de Lisboa, 2011, no. 21, pp. 183-210.

10. Harrison E. B. The Web of History: A Conservative Reading of the Parthenon Frieze. Niels J. (ed.). Worshipping Athena: Panathenaia and Parthenon. Madison, University of Wisconsin Press Publ., 1996, pp. 198-214.

11. Hurwitt J. M. The Athenian Acropolis, History, Mythology and Archaeology from the Neolithic Era to the Present. Cambridge University Press Publ., 1999. 408 p.

12. Gabrielsen V. The Naukrariai and the Athenian Navy. Classica \& Medevalia, 1985, vol.36, pp. 21-51.

13. Jenkins I. D. The Parthenon Frieze. London, British Museum Press Publ., 1994. 119 p.

14. Jenkins I. D. The Composition of the So-Called Eponymous Heroes on the East Frieze of the Parthenon. American Journal of Archaeology, 1985, Centennial Issue 89, no. 1, pp. 121-127.

15. Lambert S. D. The Phratries of Attica (Michigan Monographs in Classical Antiquity. Ann Arbor, The University of Michigan Press Publ., 1998. 440 p. 
16. Manville Ph. The Origins of Citizenship in Ancient Athens, Princeton Legacy Library Publ., 1990. 280 p.

17. Marcaccini C. The Treasurers of Athena in the Late $5^{\text {th }}$ Century B. C. When Did They Take Office. Hesperia, 2015, vol. 84, pp. 515-532.

18. Martin A. Les cavaliers Athéniens (BÉFAR 47). Paris, Ernest Thorin Publ., 1887. 588 p. (in French).

19. Nagy B. Athenian Officials on the Parthenon Frieze. American Journal of Archaeology, 1992, vol. 96, no. 1, pp. 55-69.

20. Neils J. The Parthenon Frieze. Cambridge, Cambridge University Press Publ., 2001. 313 p.

21. Neils J. With Noblest Images on All Sides: The Ionic Frieze of the Parthenon. Neils J. (ed.). The Parthenon: From Antiquity to the Present. Cambridge, Cambridge University Press Publ., 2005, pp. 199-223

22. Pollitt J. J. The Meaning of the Parthenon Frieze. Buitron-Oliver D. (ed.). The Interpretation of Architectural Sculpture in Greece and Rome. Washington, D. C., National Gallery of Art Publ., 1997.

23. Pritchard D. M. The Horsemen of Classical Athens. Some Considerations on Their Recruitment and Social Background. Athenaeum, 2018, vol. 106, no. 2, pp.439-453.

24. Schuchardt W. Die Entstehung des Parthenonfrieses. Jahrbuch des Deutschen Archäologischen Instituts, 1930, vol. 44, pp. 218-280 (in German).

25. Shear J. L. Serving Athena. The Festival of the Panathenaia and the Construction of Athenian Identities. Cambridge University Press Publ., 2021. 500 p.

26. Spence I. G. The Cavalry of Classical Greece: A Social and Military History with Particular Reference to Athens. Oxford, Oxford University Press Publ., 1993. 346 p.

27. Stevenson T. The Parthenon Frieze in Recent Scholarship: Problems and Interpretations. Ancient History, 2000, vol. 30, no. 1, pp. 42-67.

28. Traill J. S. The Political Organization of Attica, Hesperia, Supplement 14, Princeton, 1975. xviii, 135 p.

29. Worley L. J. Hippeis. The Cavalry of Ancient Greece. Westview Press: Boulder, San Francisco, Oxford, 1994. xiii, $241 \mathrm{p}$.

30. Woronoff M. Chevaux et cavaliers en Grèce antique. Academie des Sciences et Lettres de Montpelier, Comunications présentées en 2010, 2010, pp.212-222 (in French).

Title. The Great Frieze of the Parthenon and the Organization of the Athenian Society under the Democracy of Pericles.

Author. Mavrogiannis, Theodoros - Ph. D., professor. University of Cyprus. Kallipoleos 75, P. O. Box 20537 1678, Nicosia, Cyprus. theomav@ucy.ac.cy

Abstract. It is strange enough that, although several attempts were made to discern the criteria upon which the representation of the Athenians on the Parthenon-Frieze is based, there is no still consensus about the structure of the composition rendering the procession in honour of Athena, whether it was an idealized, thus an exemplary depiction of the Panathenaia on $15^{\text {th }}$ Hecatombeon, when the entire population of Athens would be reunited in his social components, or a historical relief issued by the celebration of the feast in a given date between 447 and $432 \mathrm{~B}$. C. The problem lies in the fact that the population of the Athenian citizens was strictly organized according to institutions, going back as far as the timocratic reform of Solon in 591 B.C., which established the subdivision in four classes of citizens on the grounds of the revenues deriving from the land property. L. Beschi thought to have recognized that the composition revealed the new subdivision of Athenians in 10 territorial tribes following the Democratic revolution of Cleisthenes in 509 B. C. But the absence from the Frieze of the lower and most populous class of citizens, the thetai, who in fact acquired a major weight after the battle at Salamis in 480 B. C., creates a lot of problems. In as much, the preeminent presence of the Athenian cavalry in the Frieze may suggest that the Democracy of Pericles was not yet entered the radical way, as it is thought for the period after the abolition of the privileges of the Council of Areios Pagos in 461 B. C. put forward by Ephialtes, the mentor of Pericles. Unfortunately, we do not know all the institutional reforms introduced by Pericles after 447 B. C., whether the daily wages to be afforded by the State to the 500 bouleutai and the elected members of the tribunal of Heliaia were accompanied by a military reform of the cavalry. What seems to be true is that the Democracy of Pericles has preserved a class of aristocracy, which appears only in the Frieze, to be identified with the two upper classes of the Solonian constitution. We do not have, therefore, at our disposal any clue to ascertain that the Solonian constitution was abolished or surpassed by the new Democratic institutions. In fact, the number of the knights in the Frieze of Parthenon 144, as they are represented in units of 3 knights, should be precise, and not indicative, of the recruitment of the cavaliers through the 48 naucrariai, the ancient territorial districts for the levies of the State of Solon. It should be remembered that an outstanding position in 
the Frieze is reserved to the metoikoi, the strangers domiciliating in Athens who contributed to the organization of the feasts, because of their wealth. Thus, we will stress to explain the most profound structure of the Athenian society by reevaluating the iconography of the Great Frieze of Parthenon.

Keywords: Parthenon, Athens, Pericles, reliefs of the great frieze, art and society

Название статьи. Композиция большого фриза Парфенона и организация афинского общества в эпоху демократии Перикла

Сведения об авторе. Маврояннис Теодорос - Ph. D., профессор. Кипрский университет, Кallipoleos 75, Р. О. Вох 20537 1678, Никосия, Кипр. theomav@ucy.ac.cy

Аннотация. В статье анализируется проблема представительства различных слоёв афинского общества в изобразительной программе Парфенона. Автор высказывает суждение о том, что до настоящего времени среди исследователей нет единого мнения о структуре композиции, изображающей Панафинейскую процессию в рельефах большого фриза главного храма Афин. Главный вопрос следовало бы сформулировать так: изображают ли рельефы главного фриза Парфенона некое идеализированное шествие во время великих Панафиней, когда всё население Афин объединяется, независимо от своего социального положения, или это исторический документ, созданный для увековечивания празднования в какой-то определённый день между 447 и 432 гг. до н. э. Население Афин, согласно законам Солона 591 г. до н. э., было строго организовано и подразделялось на четыре класса граждан, исходя из их доходов от земельной собственности. Луиджи Бески считал, что композиция подразумевает деление афинян на 10 территориальных фил, появившихся в результате реформ Клисфена в 509 г. до н. э. Однако отсутствие на фризе представителей низшего и наиболее многочисленного класса граждан - фетов, которые фактически приобрели большой вес после битвы при Саламине в 480 г. до н. э., создает множество проблем. Принимая во внимание, что главное место в рельефах фриза отведено афинской кавалерии, можно допустить, что демократия Перикла еще не вступила на тот радикальный путь, которым пошло общество после реформы Эфиальта 461 г. до н. э. об отмене привилегий ареопага. К сожалению, у нас нет достаточных сведений обо всех реформах Перикла, предпринятых после 447 г. до н.э., особенно в части государственных выплат и преобразований, относящихся к высшему классу афинского общества. Наиболее вероятно, что демократия Перикла сохранила класс аристократии, который появляется только во фризе и должен отождествляться с двумя высшими классами эпохи Солона. Следовательно, в нашем распоряжении нет достаточных оснований, подтверждающих, что законы Солона были отменены или заменены новыми демократическими институтами. Фактически, количество всадников на фризе Парфенона 144, они представлены группами по трое, что в точности соответствует набору воинов от 48 навкрарий, древних территориальных округов, учреждённых для государственных сборов ещё Солоном. Заметное положение во фризе отведено метекам, иноземцам, проживавшим в Афинах и своими средствами вносившим существенный вклад в организацию празднества. Таким образом, переосмыслив иконографию большого фриза Парфенона, мы можем глубже понять структуру афинского общества.

Ключевые слова: Парфенон, Афины в эпоху Перикла, рельефы большого фриза, искусство и общество 